\title{
Taxation and Regulation of Financial Markets: Working Towards a Hard Fought Equilibrium
}

\section{Francesco Menoncin and Paolo M. Panteghini*}

Department of Economics and Management, University of Brescia, Italy

The sub-prime mortgage crisis in the USA followed by the sovereign debt crisis in Europe has shown how important it is to redesign fiscal systems so as to adapt them to systemic risks both today and in the future. At the moment, market stability has been mainly achieved through interventions of both monetary authorities and supra-national institutions. The Stability Financial Board, the elaboration of the new Basel III requirements, and not least, the first (and hard fought) steps towards coordination of banking controls at a European level are part of the efforts to re-design financial regulations.

As such, the monetary and financial policies reviewing the control and management mechanisms and the fiscal debate with the few proposals have come about more as a result of emotions than any wellconceived idea of efficiently re-establishing the taxation of financial assets. This is all the more paradoxical given the real morass that, starting in 2008, hit the public finances of many countries. Unfortunately, the answer of many governments (such as the United States, France, Germany, Great Britain and Italy) was the introduction of almost purely punitive levies on banks, accused of having caused the crisis.

This is also true for the so-called Financial Activities Tax (FAT) proposed by the European Commission and aimed at adding "sand to the gears" of speculation. The idea of implementing this $\operatorname{tax}^{1}$ comes from the desire to curtail the excesses of the financial industry. With this measure, policymakers hope to make trading more onerous thereby limiting the number of speculative transactions (exploded with increasing computerization of sales). However, the proposal has been developed with no adequate cost-benefit analysis. In particular, it is unclear how this tax can be effective for at least three reasons. Firstly, not all members of the EU (the UK in particular) agree on this tool; it is thus likely that a transaction tax implemented by some EU members creates distortions inside the European market. Secondly, given the dramatic increase in over the counter transactions, Europe may suffer from capital outflows toward tax-free platforms. Thirdly, this transaction tax may have a negative effect on hedging activities. In other words, since FAT also discourages investors aimed at insuring their activities against excessive risk, it is expected to cause a deadweight loss in financial markets. Furthermore, since FAT reduces the effectiveness of derivatives in hedging risk, it could even stimulate the trading of financial derivatives if agents are willing to pay more for reaching the same hedging degree as in the pre-tax framework.

Curiously, with the exception of the International Monetary Fund, no one has actually asked the "right" question, that is whether and on what terms the tax distortions may have aggravated the effects of the

${ }^{1}$ In the early Seventies James Tobin (Nobel Prize for Economics 1981) proposed taxing short-term transactions on foreign exchange markets in order to reduce the volatility of exchange rates between currencies. His proposal was aimed at making central bank actions more effective while freeing them of worrying about the consequences these monetary policies would have on exchange rates. In 1997, Ignacio Ramonet, editor of "Le Monde diplomatique" called for the creation of a movement for the application of such a tax on all financial transactions to help reduce speculation in financial markets and, at the same time, increase Governments' tax revenue. Following the financial crisis of 2007/2008, many Governments began to think seriously about whether to discourage the use of derivatives for speculative purposes by means of a suitable form of taxation based on that proposed by Tobin. crises since 2007. The IMF economists [1] have pointed out that the current tax systems favor excessive indebtedness for both corporations and families (mainly when purchasing homes). For this reason, they believe that financial leverage has amplified the effects of the crisis and that, if appropriate action is not taken, they could happen again in the future.

In this sense, it would be desirable a greater fiscal coordination at a European level. Yet, despite the numerous European documents published, since the 21-year-old Ruding Report [2], there has been no significant steps towards a tax based on common tools capable of collecting revenue and at the same time, discouraging excessive debt. Unfortunately, this impasse continues despite it being clear to everyone that corporation's and households' decisions are affected by taxes [3].

These points are at the very least contributing factors of the problems linked to this long recession. As such, they need to be looked at. The time is ripe to look at these themes at a sovra-national level in order to find anequilibrium between taxation and regulation.

\section{References}

1. Keen M, Klemm A, Perry V (2010) Tax and the Crisis. Fiscal Studies 31: 43-79.

2. Report of the Committee of Independent Experts on Company Taxation (1992) Commission of the European Communities.

3. IMF (2009) Debt Bias and Other Distortions: Crisis-Related Issues in Tax Policy, Fiscal Affairs Department.

*Corresponding author: Paolo M. Panteghini, Professor, Department of Economics and Management, University of Brescia, Italy, Tel: 39-030-2988816; Fax: 39-0302988837; E-mail: panteghi@eco.unibs.it

Received January 10, 2013; Accepted January 16, 2013; Published January 17 2013

Citation: Menoncin F, Panteghini PM (2013) Taxation and Regulation of Financial Markets: Working Towards a Hard Fought Equilibrium. J Bus \& Fin Aff 2: e134. doi:10.4172/2167-0234.1000e134

Copyright: (c) 2013 Menoncin F, et al. This is an open-access article distributed under the terms of the Creative Commons Attribution License, which permits unrestricted use, distribution, and reproduction in any medium, provided the original author and source are credited. 